\title{
PERLINDUNGAN LUMBA-LUMBA SEBAGAI SATWA LANGKA YANG DILINDUNGI DARI TINDAKAN PENEMPATAN DAN ATRAKSI HIBURAN YANG TIDAK SESUAI
}

\author{
Vivian Fanny \\ (Mahasiswa Program S1 Fakultas Hukum Universitas Tarumanagara) \\ (E-mail: vvianfannys@gmail.com)
}

\begin{abstract}
Ahmad Redi
(Corresponding Author)

(Dosen Hukum Tata Negara Universitas Tarumanagara, Meraih Sarana Hukum (S.H.) dari Universitas Diponegoro (2007), Magister Hukum (M.H.) dari universitas Indonesia (2009), dan Doktor ilmu hukum (Dr.) dari universitas Indonesia (2013)

(Email: ahmadr@untar.ac.id)
\end{abstract}

\begin{abstract}
The emerging of entertainment development in Indonesia, increasing number of tourists is one aspect for the world entertainment competition. The increasing insistence and urge in the world of entertainment making the business perform a variety of ways in order to survive and able to compete in the competition. One of the example is the dolphins entertainment, they do a lot of tricks and do interact directly to human. Apart from all the entertainment that we get as the consumer, we do not know how the way dolphins suffer of to do all the orders given for the tricks, to do the direct interaction without injuring humans. All things they went through was a hard painfuly and unpleasant process. As a protected species, the care maintenance and ownership rules should be followed for the sake of the animal welfare. The protection of dolphins entertainment considered as important and should be monitored according the rules to avoid animal abuse.
\end{abstract}

Keywords : endangered species protection, dolphin, abuse 


\section{PENDAHULUAN}

\section{A. Latar Belakang}

Manusia sebagai makhluk hidup terus mengalami perkembangan. Dengan adanya perkembangan pada diri manusia tentunya memerlukan kebutuhan yang bertambah juga seiring dengan berjalannya waktu. Kebutuhan manusia manusa yang tidak terbatas dipengaruhi oleh perkembangan zaman. Kebutuhan itu sendiri dibagi menjadi kebutuhan primer, kebutuhan sekunder, dan kebutuhan tersier. Menurut Teori Maslow, kebutuhan manusia sangat penting untuk dipenuhi hingga apabila salah satu kebutuhan tidak terpenuhi maka manusia akan sulit menjalankan peran dan fungsinya. ${ }^{1)}$ Salah satu bentuk dari kebutuhan tersier adalah hiburan. Hiburan dibutuhkan oleh manusia dengan memberikan kesenangan kepada dirinya untuk menghilangkan kepenatan setelah beraktifitas di dalam kehidupan sehari-hari. Indonesia memiliki banyak destinasi hiburan. Pariwisata menjadi peringkat ke-empat dalam ranking devisa Indonesia setelah hasil sumber daya alam Indonesia seperti gas bumi dan batu bara. ${ }^{2)}$

Indonesia merupakan negara kepulauan dengan berbagai bentuk geografis yang berbeda-beda dari Sabang hingga Merauke. Indoneisa memiliki kombinasi iklim tropis, 17.504 pulau ${ }^{3)}$, tujuh lokasi di Indonesia titetapkan oleh UNESCO masuk dalam daftar Situs Warisan Dunia. ${ }^{4)}$ Mulai dari hutan tropisnya yang luas, pegunungan hingga laut membentang yang luas. Begitu banyak wilayah yang bisa dijadikan tujuan wisata. Pusat destinasi wisata dengan hiburan yang menarik wisatawan domestik maupun mancanegara.

1) Abraham H. Maslow, Motivasi dan Kepribadian 1 - Teori Motivasi Dengan Pendekatan Hierarki Kebutuhan Manusia, (Jakarta: PPM,1993)

2) Anonim, "Ranking Devisa Pariwisata terhadap Komoditas Ekspor Lainnya", http://www.kemenpar.go.id/asp/detil.asp?c=117\&id=1198, diakses tanggal 24 Juni 2018

${ }^{3)}$ Dody Usodo Hargo, "Jumlah Pulau di Indonesia”, https://dkn.go.id/ruang-opini/9/jumlahpulau-di-indonesia.html, diakses tanggal 24 Juni 2018.

${ }^{4)}$ Anonim, "World Heritage List", http://whc.unesco.org/en/list, diakses tanggal 24 Juni 2018 
Salah satu wilayah yang dijadikan tujuan wisata di Indonesia ada di Bali. Bali memiliki berbagai macam hiburan mulai dari destinasi tempat berpemandangan indah sampai dengan hiburan menyenangkan yang disediakan di tempat penginapan yang kita tempati.

Dengan meningkatnya kebutuhan liburan dan hiburan, dari wisatawan domestik maupun mancanegara, setiap pengusaha bersaing untuk membuat usaha hiburan mereka lebih menarik daripada dengan tempat yang lainnya. Salah satunya adalah Hotel dan Resort yang ada di Bali menyediakan dolphin pool yang membuat para wisatawan tertarik pada Hotel dan Resort tersebut.

Kita sebagai pihak konsumen hanya bisa membeli dan menerima jasa hiburan, tetapi kita tidak tahu bagaimana mereka, hewan-hewan yang dipergunakan untuk hiburan kita diperlakukan untuk memanjakan keinginan kepuasan kita sebagai manusia. Banyak di antara mereka disiksa demi yang dinamakan "didikan" untuk menuruti apa yang dikatakan sang pawang atau pelatih. Bahkan mereka terpaksa untuk tinggal dan berada di dalam kolam dengan kandungan klorin yang berbahaya bagi mereka, hal ini sudah termasuk suatu tindak pidana penyiksaan. Pemberitaan juga sering menyoroti tindakan kekerasan yang dialami lumba-lumba yang konon mengalami kekerasan fisik maupun psikis dan pemaksaan agar patuh saat melakukan atraksi, memanfaatkan lumba-lumba ini untuk kepentingan memperoleh penghasilan dengan mengabaikan hak-hak hidup hewan bahkan menganiaya mereka. ${ }^{5)}$

Nyatanya lumba-lumba di resort Bali ini ditempatkan di kolam renang yang tidak begitu luas dan kolam yang berada tidak jauh dari pantai sendiri, tempat asli dimana seharusnya mereka berada. Penempatan Kolam yang ditempati mereka hanya sebesar 10 meter x 20 meter, sedangkan di dalam

5) Dian Equanti, "Mengenal Prinsip Kesejahteraan Hewan (Animal Welfare Principle)", http://www.kompasiana.com/dianequa/mengenal-prinsip-kesejahteraan-hewan-animal-welfareprinciple 568b2f6e3dafbdc30ed27bf2, diakses tanggal 5 April 2017. 
kolam itu terdapat lebih dari dua ekor lumba-lumba. Lumba-lumba dapat berenang hingga ratusan kilometer di laut bebas tetapi di dalam kolam ruang gerak mereka menjadi sangat terbatas. Tingginya kadar klorin di dalam kolam membuat lumba-lumba menjadi rabun dan berujung dengan kebutaan. Lumbalumba yang cacat buta dipisahkan dari kolam besar ke kolam yang lebih kecil dan menyendiri. Stress yang dihasilkan dari ketakutan, kecemasan, frustrasi, dan penangkapan, serta kebosanan dan isolasi, dapat menyebabkan penurunan psikologis dan perubahan fisik yang dapat menyebabkan penyakit berkepanjangan dan kematian. ${ }^{6)}$ Lumba-lumba sendiri merupakan satwa mamalia yang di lindungi. Di dalam Peraturan Pemerintah Nomor 7 Tahun 1999 di dalam lampirannya tertulis dalam bagian mamalia, lumba-lumba air laut semua jenis dari family Ziphiidae. Maka perawatan dan pengawasannya haruslah dengan baik dan ketat.

Menurut Undang-Undang Nomor 18 Tahun 2009 tentang Peternakan dan Kesehatan Hewan, kesejahteraan hewan adalah segala urusan yang berhubungan dengan keadaan fisik dan mental hewan menurut ukuran perilaku alami hewan yang perlu diterapkan dan ditegakkan untuk melindungi hewan dari perlakuan setiap orang yang tidak layak terhadap hewan yang dimanfaatkan manusia. Undang-Undang Peternakan dan Kesehatan Hewan) sendiri sudah mengatur tentang kesejahteraan hewan di dalam Pasal 66 ayat (1) Untuk kepentingan kesejahteraan hewan dilakukan tindakan yang berkaitan dengan penangkapan dan penanganan; penempatan dan pengandangan; pemeliharaan dan perawatan; pengangkutan; pemotongan dan pembunuhan; serta perlakuan dan pengayoman yang wajar terhadap hewan. Dalam Pasal 66 ayat (2) huruf b menyebutkan penempatan dan pengandangan dilakukan dengan sebaik-baiknya sehingga memungkinkan hewan dapat mengekspresikan perilaku alaminya.

6) Nick Carter, "effect of psycho-psychological stress on captive dolphins", The Humane Society Institute for Science and Policy Anial Studies Repository, Edisi No. 3 Tahun 1982, hal. 194. 
Dalam Pasal 66 ayat (2) huruf c menyebutkan pemeliharaan, pengamanan, perawatan, dan pengayoman hewan dilakukan dengan sebaikbaiknya sehingga hewan bebas dari rasa lapar dan haus, rasa sakit, penganiayaan dan penyalahgunaan, serta rasa takut dan tertekan. Dalam huruf e dan g menjelaskan penggunaan dan pemanfaatan hewan dilakukan dengan sebaik-baiknya sehingga hewan bebas dari penganiayaan dan penyalahgunaan dan perlakuan terhadap hewan harus dihindari dari tindakan penganiayaan dan penyalahgunaan. Dalam Kitab Undang-undang Hukum Pidana (yang selanjutnya disebut KUHP) juga mengatur pidana terhadap orang yang melakukan penyiksaan terhadap hewan. Dalam Pasal 302 KUHP menentukan:

(1) Diancam dengan pidana penjara paling lama tiga bulan atau pidana denda paling banyak empat ribu lima ratus rupiah karena melakukan penganiayaan ringan terhadap hewan:

1. barang siapa tanpa tujuan yang patut atau secara melampaui batas, dengan sengaja menyakiti atau melukai hewan atau merugikan kesehatannya;

2. barang siapa tanpa tujuan yang patut atau dengan melampaui batas yang diperlukan untuk mencapai tujuan itu, dengan sengaja tidak memberi makanan yang diperlukan untuk hidup kepada hewan, yang seluruhnya atau sebagian menjadi kepunyaannya dan ada di bawah pengawasannya, atau kepada hewan yang wajib dipeliharanya.

(2) Jika perbuatan itu mengakibatkan sakit lebih dari seminggu, atau cacat atau menderita luka-luka berat lainnya, atau mati, yang bersalah diancam dengan pidana penjara paling lama sembilan bulan, atau pidana denda paling banyak tiga ratus rupiah, karena penganiayaan hewan. 
(3) Jika hewan itu milik yang bersalah, maka hewan itu dapat dirampas.

(4) Percobaan melakukan kejahatan tersebut tidak dipidana.

Aturan-aturan di atas sudah sangat jelas akan adanya sanksi apabila masyarakat masih melakukan tindakan penganiayaan dan penyalahgunaan terhadap hewan. Seharusnya pemeliharaan dan perawatan hewan harus dilakukan dengan baik dan sesuai dengan aturan. Melukai atau merusak kesehatan hewan demi kepuasan dan/atau keuntungan dari hewan dengan memperlakukan secara tidak wajar dapat diancam dengan pidana penjara paling lama tuga bulan atau denda paling banyak empat ribu lima ratus rupiah. Meskipun sanksi yang diberikan seharusnya sudah direvisi dan besar sanksinya disesuaikan dengan tindakan yang dilakukan. Sirkus atau pertujukan lumba-lumba masih tetap ada di Indonesia dan program yang memungkinkan anda berenang bersama dengan lumba-lumba adalah penyebab atas penderitaan yang sedang dialami oleh mamalia laut yang menakjubkan, pintar dan sosial ini. Wahana semacam ini adalah bentuk pariwisata yang sangat tidak bertanggungjawab, karena mendukung satwa untuk dieksploitasi hingga sakit dan mati. Manusia dianggap tidak memiliki hak untuk membuat satwa menderita dan sudah selayaknya meningkatkan derajat kesejahteraannya dengan perlakuan yang lebih "manusiawi". 7)

Perlindungan keragaman hayati juga terkait dengan masalah pencegahan, sebab mencegah kepunahan jenis dan keberagaman hayati diperlukan pencegahan dini. $^{8)}$ Manusia telah memasukkan alam dalam kehidupan budayanya, tetapi kerap melupakan bahwa ia merupakan bagian dari alam

\footnotetext{
7) John Webster, Animal Welfare A Cool Eye Towards Eden, (Willey-Blackwel, 1995), hal. 3.

8) Syamsuharya Bethan, Penerapan Prinsip Hukum Pelestarian Fungsi Lingkungn Hidup dalam Aktivitas Industri Nasional, (Jakarta: PT Alumni, 2008), hal. 99.
} 
tempat kehidupannya.9) Kematian dari lumba-lumba yang mengakibatkan kebutaan dan stress juga langsung digantikan dengan lumba-lumba lainnya yang diambil langsung maupun diberikan pengganti yang baru. Dengan dalih penangkaran, pihak yang berdalih sebagai penangkar ini mengirim lumbalumba baru untuk menggantikan yang sakit maupun mengambil langsung dari laut lalu dijual kembali kepada pihak pengusaha. Lumba-lumba yang sakit selanjutnya ditukarkan dan diserahkan ke pihak penangkaran.

Penangkaran menurut Pasal 7 Peraturan Pemerintah Nomor 8 Tahun 1999 tentang Pemanfaatan Jenis Tumbuhan dan Satwa Liar (yang selanjutnya disebut PP Pemanfaatan Jenis Tumbuhan dan Satwa Liar), merupakan bentuk pemanfaatan, dan dapat dilakukan dengan dua cara, yakni:

1) pengembangbiakan satwa dan perbanyakan tumbuhan dan

2) penetasan telur atau pembesaran anakan yang diambil dari alam. Sedangkan pengembangbiakan, menurut Pasal 16 Peraturan Pemerintah 7 Tahun 1999 tentang Pengawetan Jenis Tumbuhan dan Satwa (yang selanjutnya disebut PP Pengawetan Jenis Tumbuhan dan Satwa), merupakan pengelolaan di luar habitat (ex-situ) untuk pengembangan populasi di alam agar tidak punah.

Penangkaran itu sendiri tidak memenuhi syarat tentang pengembangbiakannya, karena tindakan pengambilan langsung dari alam bukan dari pengembangbiakan. Maka dari itu dibutuhkan penandaan pada lumba-lumba untuk mengetahui identifikasi, perkembangan dan kesehatan saat ada pemeriksaan oleh penyidik.

Banyaknya kasus penyiksaan hewan lumba-lumba dalam hiburan lumbalumba, pemerintah seakan tutup mata, ikut menikmati hiburan penyiksaan itu dan juga menyetujui terselenggaranya acara tersebut. Undang-Undang Peternakan dan Kesehatan Hewan Pasal 84 ayat (1) menyebutkan, Selain

9) Koesnadi Hardjasoemantri, Hukum Tata Lingkungan, (Yogyakarta: Gadjah Mada University Press, 1994), hal. 4. 
Pejabat Penyidik Kepolisian Negara Republik Indonesia, Pejabat Pegawai Negeri Sipil tertentu yang lingkup tugas dan dari tanggungjawabnya meliputi peternakan dam kesehatan hewan diberi wewenang khusus sebagai penyidik sesuai dengan ketentuan peraturan perundang-undangan. Sebenarnya para Pejabat Penyidik Pegawai Negeri Sipil memiliki kewenangan sendiri sebagaimana dimaksud dalam Pasal 84 ayat (2) yaitu Pejabat Penyidik Pegawai Negeri Sipil sebagaimana dimaksud pada ayat (1) huruf a berwenang untuk melakukan pemeriksaan atas kebenaran laporan atau keterangan berkenaan dengan tindak pidana di bidang peternakan dan kesehatan hewan.

Pelanggaran-pelanggaran terhadap hewan ini tidak terlepas dari pelindungan hukum terhadap kesehatan hewan dan kesejahteraan hewan tersebut terutama penerapan sanksi pidananya. Penetapan sanksi pidana ini tidak terlepas dari tujuan pemidanaan itu sendiri tetapi untuk mengukur sejauh mana penerapan sanksi pemidanaan itu dapat mencapai tujuan secara efektif. Hewan telah menjadi bagian dan akan terus digunakan dalam hiburan, sering untuk merugikan binatang. Sementara hukum membantu dalam melarang dan mengatur praktek-praktek tertentu, permintaan itu untuk hiburan lah yang akan selalu menjaga bisnis terus berkembang. ${ }^{10)}$

Banyaknya permasalahan maupun aduan-aduan atas kesejahteraan hewan melahirkan suatu kelompok atau organisasi pecinta hewan dan penyelamat hewan. Kelompok dan organisasi tersebut membantu menyelamatkan, menolong, menampung ataupun memberikan edukasi mengenai hewan. Salah satunya adalah Jakarta Animal Aid Network (JAAN). Jakarta Animal Aid Network atau dikenal sebagai JAAN didirikan pada Februari 2008 oleh Femke den Haas, Karin Franken dan Natalie Stewart sebagai tempat pusat orang dapat menghubungi/kasus laporan penyalahgunaan hewan atau mencari tahu informasi tentang kesejahteraan hewan di Indonesia. Jakarta Animal Aid

\footnotetext{
10) Jennifer "Animals Dragotta, in Entertainment", https://www.learningtogive.org/resources/animals-entertainment, diakses tanggal 23 Juni 2018.
} 
Network dibagi menjadi 2 bagian yaitu Domestik dan Wildlife. Wildlife Rescue mencakup semua kasus yang kita berurusan dengan mengenai primata, lumba-lumba, harimau, orangutan dan banyak lagi.

Salah satu kampanye terkaitnya yaitu "Selamatkan Lumba-Lumba Indonesia" yang sudah pro-aktif dengan penyelamatan lumba-lumba sejak 2009. MOU sudah ditandatangani oleh Departemen Kehutanan terkait penyelamatan, rehabilitasi dan pelepasan ke alam di tahun 2010. Jakarta Animal Aid Network mendapat bantuan dari Ric O’ Barry, seorang aktivis lumba-lumba untuk membangun pusat rehabilitasi lumba-lumba permanen di Karimun Jawa. Pentingnya pengaturan penempatan dan penangkaran dibutuhkan agar menjamin kesehatan dan kelangsungan hidup lumba-lumba yang terbilang cukup lama di alam bebas, tetapi terlalu singkat untuk lingkungan kegiatan hiburan. Kebebasan dari hewan sendiri juga menjadi salah satu pendukung dari pentingnya pengaturan itu sendiri. CEO dari Animals International, Sue Arnold mengatakan

"Tidak ada negara dengan undang-undang pencegahan kekejaman akan membiarkan perlakuan tidak berperasaan dan brutal ini kepada hewan tak berdaya. Kondisi yang membuat kebutaan pada lumba-lumba tawanan menyebabkan rasa sakit yang begitu besar dan menderita.

Untuk menggunakan hewan-hewan ini untuk membuat uang sebagai 'hiburan' bagi wisatawan cabul. Kecuali Pemerintah Indonesia bertindak untuk menutup fasilitas ini, pariwisata dan reputasi internasional Indonesia akan menderita. Organisasi konservasi, operator pariwisata semua menerima banyak panggilan telepon dan email dari orang-orang yang terkejut dengan perlakuan terhadap lumba-lumba di Indonesia.",11)

Masyarakat perlu tahu dan ikut dalam menegakkan perlindungan terhadap hewan-hewan mengenai kesejahteraannya. Bukan hanya masyarakat saja, tetapi pemerintah juga ikut turut serta dalam penegakkan ini karena upaya

${ }^{11)}$ Shyafira, "Jakarta Animal Aid Network" https://www.jakartaanimalaid.com/about/, diakses tanggal 28 Desember 2017. 
masyarakat saja tidak cukup. Peran serta masyarakat memerlukan penyaluran informasi kepada masyarakat dengan cara yang berhasil guna dan berdaya guna. ${ }^{12)}$ Butuh pengembangan dan pendidikan akan kepedulian ini, seperti yang kita tahu masyarakat Indonesia masih kurang peduli dan kurang mengetahui pentingnya kesejahteraan hewan itu sendiri. Berdasarkan hal tersebut di atas penulis akan melakukan penelitian yang berjudul Perlindungan Lumba-Lumba Sebagai Satwa Langka Yang Dilindungi dari Tindakan Penempatan dan Atraksi Hiburan Lumba-Lumba yang Tidak Sesuai.

\section{B. Perumusan Masalah}

Berdasarkan hal tersebut di atas penulis akan melakukan penelitian perlindungan lumba-lumba dari tindakan penempatan dan atraksi hiburan yang tidak sesuai ?

\section{PEMBAHASAN}

Perlindungan hewan di Indonesia diatur di dalam Undang-undang Nomor 5 Tahun 1990 tentang Konservasi Sumber Daya Alam Hayati dan Ekosistemnya. Diadakannya perlindungan hewan guna melindungi hewan dari kepunahan dan juga menjaga kelestariannya terhadap ekosistem di lingkungan Indonesia. Pentingnya peranan unsur dalam pembentukan lingkungan hidup bersifat mutlak serta tak tergantikan. Upaya pencegahan terhadap kepunahan itu adalah perlindungan terhadap fauna yang bersangkutan. ${ }^{13)}$ Undang-undang ini dianggap sudah terlalu ketinggalan zaman dan tidak relevan lagi untuk menghadapi situasi yang mengancam perlindungan dan kelestarian satwa di Indonesia. Seharusnya undang-undang ini menjadi tiang kokoh untuk menjaga kelestarian dan kesejahteraan hewan yang ada di Indonesia. Kualitas

12) Koesnadi Hardjasoemantri, Aspek Hukum Peran Serta Masyarakat Dalam Pengelolaan Lingkungan Hidup, Cetakan ke-3. (Yogyakarta: Gadjah Mada University Press, 1993), hal. 4.

13) Leden Marpaung, Tindak Pidana Terhadap Hutan, Hasil Hutan, dan Satwa, (Jakarta: Erlangga, 1995), hal. 48 
lingkungan harus tetap dijaga kelestariaannya, agar selanjutnya dapat tetap mendukung kesejahteraan manusia juga. ${ }^{14)}$

Terkait dengan penelitian ini perlu diketahui bahwa lumba-lumba juga perlu memperoleh hak perlindungan dari segala pihak yang tidak bertanggung jawab terhadap perlindungan hewan. Adanya kasus terkait kesehatan dan kesejahteraan lumba-lumba oleh pihak non lembaga konservasi di Bali menjadi sorotan bagi pengamat dan pelindung hewan baik dari Indonesia maupun luar negeri. Lumba-lumba air laut dari semua jenis famili Ziphiidae termasuk dalam jenis hewan mamalia yang dilindungi. ${ }^{15)}$ Menjadi hewan yang dilindungi tentu membutuhkan pengaturan dan perawatan yang ketat apalagi untuk keperluan peragaan.

Hal ini menjadi catatan penting dan syarat bagi pemilik atau pemegang lumba-lumba dari pemerintah sampai lembaga konservasi. Pihak dari mitra yang bekerjasama dengan lembaga konservasi pun tidak luput dari peraturan yang diterapkan. Jika kita lihat di dalam pasal 30 Peraturan Pemerintah Nomor 8 Tahun 1999 tentang Pemanfaatan Jenis Tumbuhan dan Satwa Liar, mengatakan bahwa lembaga, badan atau orang yang melakukan peragaan tumbuhan dan satwa liar bertanggungjawab atas kesehatan dan keamanan tumbuhan dan satwa liar yang diperagakan dengan aturan dan standar kesehatan dan keamanan yang diberikan oleh menteri.

Pemenuhan persyaratan dan perizinan yang ketat diharap menjadi pertimbangan atas pertanggungjawaban dan pengawasan agar memenuhi kualitas terbaik. Meskipun begitu masih ada beberapa hal yang terlewat maupun tidak dilakukan dengan sesuai standar maupun aturan. Penerapan dan

${ }^{14)}$ Imam Supardi, Lingkungan Hidup dan Kelestariannya, Cetakan ke-3. (Bandung: Alumni, 1994), hal. 172.

15) Indonesia, Peraturan Pemerintah Nomor 7 Tahun 1999 tentang Pengawetan Jenis Tumbuhan dan Satwa (Lampiran Peraturan Pemerintah Nomor 7 Tahun 1999 tentang Pengawetan Jenis Tumbuhan dan Satwa) 
perlakuan di dalam lembaga, badan atau orang terhadap lumba-lumba juga harus melihat pada hak asasi hewan itu sendiri.

Pemikiran mendalam dari sepanjang zaman memiliki rasa kasihan terhadap hewan, karena mereka hidup menderita dan tidak memiliki kekuatan untuk mengubah kepedihan dari penderitaan diri mereka sendiri, dan memahami mereka sebagai suatu metafisik. ${ }^{16)}$ Hak asasi hewan sendiri di Indonesia masih terdengar aneh bagi kaum awam bahkan sangat jarang terdengar. Masyarakat lebih sering menyebut hak asasi hewan sebagai hal berkeperikehewaan.

Salah satu aliansi hewan Kanada menyetujui bahwa hewan-hewan yang digunakan dalam peragaan disalahgunakan.

"Animals in the Entertainment Industry Are Abused. Animals used in circuses, rodeos, and zoos and marine parks are exploited for profit. These animals are often housed inadequately, are subjected to cruel and abusive treatment, and experience a poor quality of life. If zoos, circuses, and other facilities are not patronized, they will not make money and will be forced to shut down, thus ending the exploitation of animals.",17)

Dia menjelaskan kondisi-kondisi yang dialami oleh hewan yang digunakan untuk hiburan sebenarnya sangat memperhatikan demi menjalankan bisnis manusia, dia juga menambahkan, "Hewan yang digunakan dalam hiburan dieksploitasi untuk keuntungan. Hal ini tidak perlu dan tidak dapat diterima." Para pendukung dari posisi filosofis sampai gerakan abolisionis setuju bahwa hewan harus dipandang sebagai orang non-manusia dan anggota komunitas moral, serta tidak digunakan sebagai makanan, pakaian, subjek penelitian ataupun hiburan. ${ }^{18)}$ Berbagai hal dilakukan dengan dasar 'dilakukan dengan cara yang benar' demi menghindari dan menutupi

${ }^{16}$ Andrew Linzey dan Paul Barry Clarke, Animal Rights: A Historical Anthology, (New York: Columbia Universirt Press,2004), 148.

17) Tamara L. Roleff, The Rights of Animals, (San Diego: Greenhaven Press, 1999),. 10

18) Anonim, Id.m.wikipedia.org/wiki/Hak_asasi_hewan, diakses tanggal 20 Desember 2017. 
komentar dan pengaduan. Menurut Tom Regan, filsuf yang bekerja dan mengabdikan pemikirannya untuk animal welfare, konservasi yang dilakukan Animal welfare tidak cukup melindungi kepentingan hewan, melainkan sebagai salah satu jalan untuk melakukan lebih banyak pembantaian legal terhadap hewan karena penggunaan atas hewan tidak dapat dipisahkan dari kekejaman.

Kepentingan dan keuntungan menjadi acuan manusia, bahkan dilakukan tanpa memikirkan hal lain diluar dirinya. Manusia sebagai makhluk hidup seharusnya tidak melakukannya, meskipun mereka melakukannya dengan cara yang 'manusiawi'. Pemberitaan juga sering menyoroti tindakan kekerasan yang dialami lumba-lumba yang konon mengalami kekerasan fisik maupun psikis dan pemaksaan agar patuh saat melakukan atraksi, memanfaatkan lumba-lumba ini untuk kepentingan memperoleh penghasilan dengan mengabaikan hak-hak hidup hewan bahkan menganiaya mereka. ${ }^{19)}$

Mereka dilatih dengan didikan 'teknik lapar' agar dapat melakukan perintah-perintah atraksi. Apabila dalam kondisi kenyang lumba-lumba tidak akan melakukan atraksi, karena makanan itu sendiri menjadi reward bagi lumba-lumba sebagai hadiah setelah menyelesaikan perintah atraksi. Lumbalumba juga pada saat pengangkutan pengiriman ke lokasi tidak diberikan makan saat perjalanan. ${ }^{20)}$ Sedangkan di dalam prinsip kebebasan dalam konsep kesejahteraan hewan sendiri meliputi:

1. Bebas dari rasa lapar dan haus;

2. Bebas dari ketidaknyamanan, penganiayaan dan penyalahgunaan;

3. Bebas dari rasa sakir, cidera dan penyakit;

19) Dian Equanti, "Mengenal Prinsip Kesejahteraan Hewan (Animal Welfare Principle)", http://www.kompasiana.com/dianequa/mengenal-prinsip-kesejahteraan-hewan-animal-welfareprinciple 568b2f6e3dafbdc30ed27bf2, diakses tanggal 5 April 2017.

${ }^{20)}$ Indonesia, Peraturan Direktur Jendral Perlindungan Hutan dan Konservasi Alam Nomor : P.16/IV-SET/2014 tentang Pedoman Peragaan Lumba-Lumba, pasal 38 
4. Bebas dari rasa takut dan tertekan; dan

5. Bebas untuk mengekspresikan perilaku alami.

Konsep dan prinsip ini tertuang di dalam Pasal 83 Peraturan Pemerintah Nomor 95 Tahun 2012 mengenai Kesehatan Masyarakat Veterenier Tahun 2012. Perlakuan dan pengayoman yang wajar pada hewan perlu diterapkan prinsip kebebasan hewan ini. Kesejahteraan hewan sendiri memiliki tiga $\operatorname{aspek~penting~}^{21)}$ :

a) Welfare science, yang mengukur efek pada hewan dalam situasi dan lingkungan berbeda yaitu dari sudut pandang hewan.

b) Welfare ethics, yaitu bagaimana manusia seharusnya memperlakukan hewan,

c) Welfare law, tentang kepedulian dan perlakuan manusia pada masingmasing hewan dalam meningkatkan kualitas hidup mereka secara individual.

Declaration of Animal Welfare (UDAW) juga menjadi sarana untuk meningkatkan kesejahteraan hewan yang isinya: ${ }^{22)}$

(1) PREAMBLE

AFFIRMING that animals are sentient beings and that their welfare is an issue worthy of consideration and respect by Member States;

(2) CONSCIOUS that humans share this planet with other species and other forms of life and that all forms of life co-exist within an interdependent ecosystem;

(3) EMPHASIZING that animal welfare should be guided by the best available science \& ethical values;

(4) RECALLING that the "five freedoms (freedom from hunger, thirst and malnutrition; freedom from fear and distress; freedom from physical and thermal discomfort; freedom from pain, injury and disease; and freedom to express normal patterns of behaviour)" provide valuable general guidance for animal welfare;

21) Wita Wahyu, Kesejahteraan Hewan bagi Kesehatan manusia, (Jakarta: Graha Media Pustaka, 2010).

${ }^{22)}$ WSPA,Draft Declaration On Animal Welfare At Universal Level - Universal Declaration on Animal Welfare, https://www.globalanimallaw.org/database/universal.html, diakses tanggal 10 Maret 2018 
(5) CONVINCED that good practices in animal welfare can have major benefits for humans and the environment, and that inclusion of animal welfare in policy discussions can strengthen efforts by governments and the United Nations on a range of issues including human and animal health, food security, poverty \& hunger reduction, disaster risk reduction \& relief, environmental sustainability and social development;

(6) WELCOMING the FAO's integration of animal welfare into its poverty alleviation, disaster relief and livestock development programmes, as outlined in the FAO Expert Meeting Report "Capacity building to implement good animal welfare practices" (2008);

(7) RECOGNIZING that many Member States already have a system of legal protection for animals, both domestic and wild, and that it is important to ensure the continued effectiveness of these systems and the development of better and more comprehensive animal welfare provisions;

(8) CONSIDERING that the promotion of animal welfare requires collective action and that all stakeholders and affected parties must be involved;

(9) ACKNOWLEDGING that the provisions contained in this declaration do not affect the rights of any Member State;

(10) NOTING Resolution XIV adopted on 24 May 2007 by the International Committee of the OIE (recognized as an international animal welfare standard-setting body) expressing support in principle for the development of a UDAW.

Peraturan mengenai kesejahteraan hewan juga diatur dalam UndangUndang Nomor 18 Tahun 2009 tentang Peternakan dan Kesehatan Hewan, pada bagian kedua dalam undang-undang ini mengatur mengenai kesejahteraan hewan. Dalam pasal 66 (2) ketentuan mengenai kesejahteraan hewan perlakuan untuk kepentingan kesejahteraan hewan dilakukan secara manusiawi meliputi:

a. Penangkapan dan penanganan satwa dari habitatnya harus sesuai dengan ketentuan peraturan perundang-undangan di bidang konservasi

b. Penempatan dan pengandangan dilakukan dengan sebaik-baiknya sehingga memunkinkan hewan dapat mengekspresikan perilaku alaminya

c. Pemeliharaan, pengamanan, perawatan dan pengayoman hewan dilakukan dengan sebaik-baiknya sehingga hewan bebas dari rasa lapar dan haus, 
rasa sakit, penganiayaan dan penyalahgunaan, serta rasa takut dan tertekan serta bebas dari penganiayaan.

Penganiayaan yang dimaksudkan disini adalah tindaka untuk memperoleh kepuasan dan/atau keuntungan dari hewan dengan memerlakukan hewan di luar batas kemampuan biologis dan fisiologis hewan. ${ }^{23}$ )

Penyalahgunaan adalah tindakan untuk memperoleh kepuasan dan/atau keuntungan dengan memerlakukan hewansecara tidak wajar dan/atau tidak sesuai dengan peruntukan untuk kegunaan hewan tersebut, misalnya pencabutan gigi lumba-lumba ${ }^{24)}$

d. Pengangkutan hewan dilakukan dengan sebaik-baiknya sehingga hewan terbebas dari rasa takut dan tertekan serta bebas dari penganiayaan

e. Penggunaan dan pemanfaatan hewan dilakukan dengan sebaik-baiknya sehingga hewan bebas dari penganiayaan dan penyalahgunaan

f. Pemotongan dan pembunuhan hewan dilakukan dengan sebaik-baiknya sehingga hewan bebas dari rasa sakit, rasa takut dan tertekan, penganiayaan, dan penyalahgunaan

g. Perlakuan terhadap hewan harus dihindari dari tindakan penganiayaan dan penyalahgunaan.

Ketentuan yang berkaitan dengan penyelenggaraan kesejahteraan hewan diberlakukan bagi semua jenis hewan bertulang belakang dan sebagia yang tidak bertulang belakang yang dapat merasakan sakit. Kata 'manusiawi' di awal kata pada pasal 66 ini dimaksudkan sebagai tindakan yang merujuk pada etika dan nilai kemanusiaan, seperti tidak melakukan penyiksaan.

Pelaksanaan peragaan sendiri salah satunya harus memperhatikan kaidah etika dan kesejahteraan hewan. ${ }^{25)}$ Lumba-lumba mengalami kerusakan penglihatan hingga buta dari dampak air kolam yang tidak sesuai dengan

23) Indonesia, Penjelasan Atas Undang-Undang Republic Indonesia Nomor 18 Tahun 2009 Tentang Peternakan Dan Kesehatan Hewan, pasal 66 ayat (2) huruf c

${ }^{25}$ Ibid. pasal 42. 
standar. Tingginya kadar klorin dapat merusak mata dari lumba-lumba, air kimia yang terkandung pada air campuran dalam kolam. Kelebihan kadar klorin juga dapat mengakibatkan gangguan kulit dan penurunan kesehatan. Sumber air kriteria kolam berasal dari air laut atau air tawar yang ditambahkan garam tanpa yodium, air ini harus disaring dengan filter, untuk menjaga kualitas air seperti kejernihan dan mengurangi material organik di dalam air. ${ }^{26)}$

Kualitas air di alam tentu berbeda dengan air yang ada pada kolam penempatan. Perbedaan kualitas air juga berefek kepada lumba-lumba itu sendiri. Lumba-lumba tentu tidak dapat menolak atau bereaksi langsung terhadap air yang ada di kolam tempat dia ditempatkan. Permasalahan pada penempatan kolam lumba-lumba, di dalam peraturan lembaga konservasi. Pengaturan mengenai kolam dan sumber air kolam harus sesuai dengan satwa. Di dalam Peraturan Direktur Jendral Perlindungan Hutan dan Konservasi Alam Nomor : P.16/IV-SET/2014 tentang Pedoman Peragaan Lumba-Lumba menjelaskan Sumber air laut yang berasal dari air laut atau air tawar yang dicampur garam tanpa sodium. Pemeliharaan kolam juga dipantau dengan baik dari berbagai aspeknya. Salah satu syarat yang harus dipenuhi yaitu, penempatan kandang dari satwa harus menyesuaikan dari bentuk tubuh dan perilaku dari satwa itu sendiri. Apabila satwa itu membutuhkan tempat yang luas maka harus dibuatkan tempat yang luas dimana ia ditempatkan. Menurut pasal 16 Peraturan Direktur Jendral Perlindungan Hutan dan Konservasi Alam Nomor : P.09/IV-SET/2011 tentang Pedoman Etika dan Kesejahteraan Satwa di Lembaga Konservasi, Tempat tinggal satwa dan kelengkapannya harus dirancang sesuai dengan kebutuhan biologis, fisik dan perilaku satwa sehingga dapat membuat satwa merasa nyaman dan aman.

Tempat tinggal satwa dan kelengkapannya harus memperhatikan :

\footnotetext{
${ }^{26}$ Ibid. pasal 9.
} 
a. Persyaratan tempat tinggal satwa;

1) Luas tempat tinggal;

2) Bahan/materi tempat tinggal;

3) Kenyamanan tempat tinggal dan kebutuhan dasar satwa

4) Peralatan tempat tinggal, kurungan, akuarium, kolam; dan

5) Pencegahan stres atau penganiayaan satwa.

Lumba-lumba sendiri berenang hingga ratusan kilometer di laut bebas sedangkan di dalam kolam mereka hanya dapat bergerak memutar di kolam buatan. Keterbatasan ruang di dalam kolam selain membatasi pergerakan lumba-lumba juga mengganggu sonar yang digunakan oleh lumba-lumba, hal ini merupakan aspek yang paling merusak dalam pempatan lumba-lumba. Sonar ini digunakan lumba-lumba saat mencari mangsa maupun mendeteksi halangan di lautan, tetapi di dalam kolam sonar itu terus memantul kembali pada dirinya saat berhadapan dengan dinding-dinding kolam. Padahal untuk pemeliharaan, perawatan dan pemanfaatan sudah memiliki standarnya dalam aturannya di dalam Pasal 14 Peraturan Direktur Jendral Perlindungan Hutan dan Konservasi Alam Nomor : P.09/IV-SET/2011 yaitu:

a. Pengelolaan Perawatan Satwa (Husbandry Management);

b. Kesehatan Satwa dan Fasilitasnya;

c. Karantina; dan

d. Pemanfaatan Satwa.

Kematian lumba-lumba dapat digantikan lagi dengan lumba-lumba yang barunya. Hasil penyelidikan dari pihak JAAN membuktikan nelayan yang menangkap lumba-lumba untuk dijual kepada pihak pembeli lumba-lumba. Semberi melaut mereka juga bisa membawa pulang lumba-lumba yang menjadi tambahan masukan uang. Dengan alasan bahwa lumba-lumba tersebut terjerat oleh jaring ikan mereka saat melaut, mereka membawa lumba-lumba itu untuk 'ditolong' dan diberikan perawatan. Padahal di dalam 
Pasal 21 ayat (2) huruf a Undang-undang Nomor 5 Tahun 1990 tentang Konservasi Sumber Daya Alam Hayati dan Ekosistemnya mengatakan bahwa setiap orang dilarang untuk menangkap, melukai, membunuh, menyimpan, memiliki, mengangkut, dan memperniagakan satwa yang dilindungi. Hal ini sudah sangat jelas dilarang untuk melakukan hal-hal tersebut. Pengecualian untuk aturan ini diperbolehkan apabila dilakukan untuk keperluan penelitian, ilmu pengetahuan, dan atau penyelamatan jenis satwa yang bersangkutan. Tetapi hal ini malah menjadi celah bagi pelaku untuk menjadikan pengecualian tersebut menjadi alasan penangkapan mereka.

Segala peraturan yang ada dan mengatur terkait lumba-lumba sebagai satwa dilindungi dan sebagai peragaan sudah diatur oleh pemerintah, tetapi masih ada celah dan kelalaian oleh pemegang lumba-lumba. Seharusnya segala bentuk hiburan peragaan lumba-lumba ditiadakan karena hal ini murni hanya sebatas bisnis. Alasan pendidikan mengenai lumba-lumba dan pengobatan hanya sebuah kedok dari bisnis ini. Karena hiburan ini memberikan masukan pendapatan juga kepada negara, hingga saat ini masih tetap berjalan. Sebuah pentas lumba-lumba bisa mengasilkan hinggal Rp8.000.000,- sebuah angka yang cukup besar. Dalam hiburan lebih menitik beratkan sisi ekonominya disbanding sisi kemanusiaan terhadap kehewanan.

Izin peragaan lumba-lumba (Pasal 9 Peraturan Menteri Kehutanan Republik Indonesia Nomor : P.40/Menhut-II/2012 tentang Peragaan Jenis Tumbuhan dan Satwa Liar Dilindungi) bahkan diperpanjang kembali, setelah sebelumnya JAAN ada mengikuti rapat dengan seketariat negara terkait hal ini. Sebelumnya pemerintah menjanjikan untuk menghentikan perijinan peragaan lumba-lumba, sehingga hal ini menjadi sebuah pertanyaan besar kepada pemerintah terkait mengapa kesepakatan yang sudah disetujui diawal berubah tiba-tiba. JAAN sendiri berharap sirkus lumba-lumba dihentikan 
karena hal ini jelas tidak sejahtera bagi satwa, kembalinya fungsi lumbalumba di alam liar, pembaruan Undang-Undang Nomor 5 tahun 1990 agar semua permasalahan mengenai kesejahteraan lumba-lumba dapat selesai teratasi. Berbagai cara diberikan dan bukti untuk membantu kasus ini, tetapi pemerintah sendiri seperti menutup telinga terhadap kasus ini, karena untuk kasus seperti ini bisa dikatakan sebagai sebuah permainan tingkat tinggi dengan petinggi negara.

Meskipun kesejahteraan hewan sudah banyak disosialisasikan dan diusahakan tetapi, belum ada penindakan lebih lanjut ataupun tindakan yang lebih serius. Pasal 302 KUHP sudah menjelaskan dan mengatur tentang perlindungan terhadap hewan. Sanksi-sanki terhadap satwa juga masih belum begitu tegas dan memberikan efek jera bagi pelaku. Masih banyaknya pelaku yang mengabaikan kesejahteraan hewan menjadi bukti nyata akan kurangnya sanksi dan ketegasan dari aturan yang berlaku.

\section{PENUTUP}

\section{A. Kesimpulan}

Berdasarkan hasil pembahasan diatas dapat disimpulkan bahwa dibutuhkan perlindungan atas lumba-lumba sendiri selain termasuk sebagai hewan yang dilindungi juga dalam hiburan peragaan dimana mereka ada di dalamnya. Pengeksploitasi yang terjadi selama ini tidak lepas dari persoalan penegakan hukum, pengawasan yang dilakukan oleh pemerintah, selama ini penegakan dan penegakan hukum lemah. Meskipun sudah ada aturan yang mengaturnya, tetapi pada nyatanya masih ada celah dan kesalahan dana tau kelalaian yang dilakukan oleh pihak pemerintah, lembaga konservasi , maupun pihak dari mitra lebaga konservasi. Karena kalau dilihat dari efektivitas penegakan hukum, ada 5 yaitu hukum/aturannya, sarana prasarana, 
penegakan hukum, budaya hukum,dan masyarakat, ini yang mempengaruhi proses penegakan hukum termasuk dalam perlindungan satwa langka. Perlu adanya perubahan norma, peninjauan kembali norma berupa perbaikan penyempurnaan aturan yang sudah ada untuk disesuaikan dengan situasi yang sedang berlangsung sekarang. aturan sendiri harus bersifat adaptif dan responsive dengan keadaan yang ada di lapangan. Dengan berubah-ubahnya situasi di masyarakat, hokum atau aturan itu juga harus disesuaikan dengan perubahan itu.

Sekarang yang terjadi hewan saat menjadi objek/alat hiburan manusia, mereka dipaksa untuk menjadi apa yang dikehendaki manusia untuk hiburannya atau atraksi hiburan. Banyak pelanggaran hak asasi hewan dan kesejahteraan hewan di dalam pementasan dan atraksi satwa. Dalam dunia hiburan lebih menitik beratkan pada sisi ekonominya disbanding sisi kesejahteraan hewan, karena manusia akan mengesampingkan hal lain diluar keuntungan apa yang akan didapatkannya. Kesehatan dan kualifikasi terhadap penempatan sudah teratur dengan rinci dan ketat, tetapi nyatanya di lapangan masih ada kelalaian dan beberapa hal yang kurang diperhatikan. Pasal 30 Peraturan Pemerintah Nomor 8 Tahun 1999 tentang Pemanfaatan Jenis Tumbuhan dan Satwa Liar mengatakan lembaga, badan atau orang yang melakukan peragaan tumbuhan dan satwa liar bertanggungjawab atas kesehatan dan keamanan tumbuhan dan satwa liar yang diperagakan.

Pentingnya menjaga kesejahteraan hewan sebagai masyarakat bersamaan dengan pemerintah sesuai dengan pasal 67 Undang-Undang Nomor 18 Tahun 2009 tentang Peternakan dan Kesehatan Hewan. Karena semua mengambil peran dalam menyelenggarakan kesejahteraan hewan, bukan hanya pemerintah tetapi masyarakat juga turut membantu dalam kesejahteraan hewan di negara Indonesia. Menjaga keberadaan dari satwa yang dilindungi agar keadaan lingkungan alam Indonesia tetap seimbang. Sehingga komunitas dan populasi hewan ini menjadi terjaga dan tidak punah, dan tidak 
tereksploitasi seperti pada kasus-kasus satwa sebagai hiburan sekarang ini. Perlindungan atas satwa di Indonesia yang dilindungi maupun yang tidak harus ditingkatkan lagi, agar satwa tidak punah, dan tidak ada perubahan dari satwa yang mulanya tidak dilindungi, menjadi dilindungi karena keberadaannya mulai hilang.

\section{B. Saran}

Sebaiknya atraksi hiburan atas lumba-lumba ditiadakan saja. Banyak pelanggaran hak asasi hewan dan kesejahteraan hewan dalam pementasan. Karena manusia akan mengabaikan hal-hal lain diluar apa yang menjadi tujuan utamanya. Dalam hal ini kegiatan atraksi hiburan akan tetap terus berjalan karena kegiatan bisnis perekonomian itu tetap berputar dan diminati. Boleh saja manfaatkan satwa untuk kepentingan hiburan tetapi perlu melihat juga hak sifat alamiah dari hewan itu, juga pengawasan terhadap kesejahteraan dan kesehatanya tetap dilakukan sesuai dengan standar aturan yang ada, bukan dibuat-buat menjadi sesuai agar bisnis hiburan dapat berjalan. Lima aspek dari efektivitas penegakan hokum harus dijalankan dan ditegakan, untuk mencapai dari penegakan hokum terhadap kesejahteraan hewan yang dituju. Perlu adanya pembaruan dan penyempurnaan terhadap aturan yang sudah ada agar lebih update dan mengatur lebih rinci lagi mengenai kesejahteraan hewan dalam hal ini terhadap kasus sebagai korban dan atau objek dari dunia hiburan satwa. Sanksi-sanki juga harus diperbarui dan lebih memberikan efek jera pada pelakunya, bagian dari pemerintah, badan maupun orang.

Sebagai manusia yang berada di posisi lebih tinggi dibandingkan mahkluk hidup lainnya, kita harusnya bisa mengetahui apa yang sepantasnya dan apa yang tidak pantas, kita harus memulai untuk membuka mata kita untuk kepedulian terhadap kesejahteraan hewan. Pemahaman masyarakat di Indonesia terhadap makna kesejahteraan hewan masih belum secara utuh, hal 
ini terkait dengan pemahaman moral, ideologi budaya dan etika di masyarakat. Terkadang, perlakuan yang tidak wajar dilakukan oleh masyarakat karena kebiasaan masyarakat yang tidak disadari atau karena ketidak tahuan, oleh karena itu sosialisasi tentang pentingnya kesejahteraan hewan kepada masyarakat harus terus dilakukan. ${ }^{27)}$

Menjaga keberadaan dari satwa yang dilindungi agar keadaan lingkungan alam Indonesia tetap seimbang. Sehingga komunitas dan populasi hewan ini menjadi terjaga dan tidak punah, dan tidak tereksploitasi seperti pada kasuskasus satwa sebagai hiburan sekarang ini. Perlindungan hewan secara merata terhadap hewan yang langka yang dilindungi maupun yang tidak dilindungi wajib dijaga populasinya dan kelestariannya guna mencegah kepunahan dini. Setiap komponen system hanya dapat berfungsi dengan baik, jika keseimbangan terjaga dengan baik atau jika perubahan keseimbangan itu tidak terjadi secara drastis. ${ }^{28)}$ Perubahan atas aturan yang sudah ada tentu diperlukan untuk disesuaikan dengan kondisi yang ada dan sesuai dengan situasi yang sedang berjalan sekarang. sudah saatnya satwa liar maupun dilindungi untuk kembali lagi di alam bebas, masih banyak cara untuk melihat dan menjumpai mereka tanpa perlu mereka ada di dalam dunia hiburan maupun atraksi, untuk mengetahu kelebihan mereka tanpa mereka dipaksakan untuk suatu kelebihan yang dipaksakan oleh manusia.

\section{Daftar Pustaka}

\section{A. Buku}

27) Aryani Widyawati, "Penerapan Kesejahteraan Hewan Di Rumah Potong Hewan", http://disnak.jabarprov.go.id/files_arsip/Artikel_Penerapan_Kesejahteraan_Hewan_di_RPH.pdf, diakses tanggal 10 maret 2018

${ }^{28)}$ Ida Bagus Wyasa Putra, Hukum Lingkungan Internasional Perspektif Bisnis Internasional. (Bandung: Refika, 2003), hal. 57. 
Andrew Linzey dan Paul Barry Clarke. Animal Rights: A Historical

Anthology. (New York: Columbia Universirt Press,2004)

Bethan, Syamsuharya. Penerapan Prinsip Hukum Pelestarian Fungsi Lingkungn Hidup dalam Aktivitas Industri Nasional. (Jakarta: PT Alumni, 2008)

Hardjasoemantri, Koesnadi. Aspek Hukum Peran Serta Masyarakat Dalam Pengelolaan Lingkungan Hidup. Cetakan ke-3. (Yogyakarta: Gadjah Mada University Press, 1993) . Hukum Tata Lingkungan. (Yogyakarta: Gadjah Mada University Press, 1994)

Marpaung, Leden. Tindak Pidana Terhadap Hutan, Hasil Hutan, dan Satwa. (Jakarta: Erlangga, 1995)

Maslow, Abraham H. Motivasi dan Kepribadian 1 - Teori Motivasi Dengan Pendekatan Hierarki Kebutuhan Manusia. (Jakarta: PPM,1993)

Putra, Ida Bagus Wyasa. Hukum Lingkungan Internasional Perspektif Bisnis Internasional. (Bandung: Refika, 2003).

Roleff, Tamara L. The Rights of Animals. (San Diego: Greenhaven Press, 1999)

Supardi, Imam. Lingkungan Hidup dan Kelestariannya. Cetakan ke-3. (Bandung: Alumni, 1994)

Wahyu, Wita. Kesejahteraan Hewan bagi Kesehatan manusia. (Jakarta: Graha Media Pustaka, 2010)

Webster, John. Animal Welfare A Cool Eye Towards Eden. (WilleyBlackwel, 1995)

B. Peraturan Perundang-Undangan

Kitab Undang-Undang Hukum Pidana

Undang-Undang Nomor 5 Tahun 1990 tentang Sumber Daya Alam Hayati dan Ekosistemnya. 
Peraturan Pemerintah Nomor 7 Tahun 1999 tentang Pengawetan Jenis Tumbuhan dan Satwa

Peraturan Pemerintah Nomor 8 Tahun 1999 tentang Pemanfaatan Jenis Tumbuhan dan Satwa Liar

Peraturan Pemerintah Nomor 95 Tahun 2012 mengenai Kesehatan Masyarakat Veteriner dan Kesejahteraan Hewan

Peraturan Menteri Kehutanan Republik Indonesia Nomor : P.40/MenhutII/2012 tentang Peragaan Jenis Tumbuhan dan Satwa Liar Dilindungi

Peraturan Direktur Jendral Perlindungan Hutan dan Konservasi Alam Nomor : P.09/IV-SET/2011 tentang Pedoman Etika dan Kesejahteraan Satwa di Lembaga Konservasi

Peraturan Direktur Jendral Perlindungan Hutan dan Konservasi Alam Nomor: P.16/IV-SET/2014 tentang Pedoman Peragaan Lumba-Lumba

C. Artikel

Anonim. "Ranking Devisa Pariwisata terhadap Komoditas Ekspor Lainnya". http://www.kemenpar.go.id/asp/detil.asp?c=117\&id=1198. Diakses tanggal 24 Juni 2018.

Anonim. Id.m.wikipedia.org/wiki/Hak_asasi_hewan. Diakses tanggal 20 Desember 2017.

Anonim. "World Heritage List". http://whc.unesco.org/en/list. Diakses tanggal 24 Juni 2018.

Carter, Nick. "effect of psycho-psychological stress on captive dolphins". The Humane Society Institute for Science and Policy Anial Studies Repository, Edisi No. 3 Tahun 1982. Diakses 5 April 2017.

Dragotta, Jennifer. "Animals in Entertainment". https://www.learningtogive.org/resources/animals-entertainment. Diakses tanggal 23 Juni 2018.

Equanti,Dian. "Mengenal Prinsip Kesejahteraan Hewan (Animal Welfare Principle)". http://www.kompasiana.com/dianequa/mengenal-prinsip- 
kesejahteraan-hewan-animal-welfare-

principle 568b2f6e3dafbdc30ed27bf2, Diakses tanggal 5 April 2017.

Hargo,Dody Usodo. "Jumlah Pulau di Indonesia". https://dkn.go.id/ruangopini/9/jumlah-pulau-di-indonesia.html. Diakses tanggal 24 Juni 2018.

Shyafira. "Jakarta Animal Aid Network" https://www.jakartaanimalaid.com/about/. Diakses tanggal 28 Desember 2017.

Widyawati, Aryani. "Penerapan Kesejahteraan Hewan Di Rumah Potong Hewan".

http://disnak.jabarprov.go.id/files_arsip/Artikel_Penerapan_Kesejahte raan_Hewan_di_RPH.pdf. Diakses tanggal 10 maret 2018.

WSPA,Draft Declaration On Animal Welfare At Universal Level Universal Declaration on Animal Welfare, https://www.globalanimallaw.org/database/universal.html, diakses tanggal 10 Maret 2018 